\title{
Does allelopathy explain the invasiveness of Campuloclinium macrocephalum (pompom weed) in the South African grassland biome?
}

\author{
Jeremy Goodall • Ed T. F. Witkowski • \\ Sigrun Ammann · Carl Reinhardt
}

Received: 25 August 2009/ Accepted: 10 March 2010

(C) Springer Science+Business Media B.V. 2010

\begin{abstract}
Campuloclinium macrocephalum is an Asteraceous alien weed that invades roadside vegetation and grassland in South Africa. The role of allelopathy and competition in its invasiveness was investigated using Eragrostis curvula (weeping lovegrass, an indigenous grass), E. tef and Lactuca sativa (lettuce) as test species. Trials were conducted in Petri-dishes, pots and in the field. Root and shoot extracts of adult $C$. macrocephalum plants did not
\end{abstract}

J. Goodall $(\bowtie)$

Agricultural Research Council (ARC), Plant Protection Research Institute, Private Bag X6006, Hilton 3245, South Africa

e-mail: goodallj@arc.agric.za

URL: www.arc-ppri.agric.za

J. Goodall · E. T. F. Witkowski

Restoration and Conservation Biology Research Group, School of Animal, Plant and Environmental Sciences, University of the Witwatersrand, Private Bag 3, Wits, Johannesburg 2050, South Africa

\section{S. Ammann}

Agricultural Research Council (ARC), Range and Forage Institute, Private Bag X6006, Hilton 3245, South Africa

C. Reinhardt

Department of Plant Production and Soil Science,

University of Pretoria, Pretoria 0002, South Africa inhibit seed germination in any test species. The greatest effect was radicle stunting produced by leaf extracts at 10 and $25 \%$ w/v. Eragrostis curvula was less tolerant of the extracts than E. tef. Allelopathic effects could however not be confirmed in pot trials evaluating the interference potential of the weed or weed residue effects against E. curvula. E. curvula growth and biomass was not affected by plant densities of one or five $C$. macrocephalum per pot, whereas $C$. macrocephalum suffered a $17 \%$ mortality and density-dependant trade-offs of size and biomass for survival. Under field conditions C. macrocephalum had a broader ecological niche than E. curvula, invading hygrophilous and undisturbed grasslands not amenable for E. curvula establishment, this included well drained disturbed soils on which the latter proliferated. Evidence of competitive exclusion of E. curvula by C. macrocephalum or vice versa was not detected. The coexistence of both species irrespective of relative density suggested these species have different resource requirements. Allelopathy was not an adequate causal mechanism to explain invasiveness in Campuloclinium macrocephalum. A more traditional hypothesis such as the absence of natural enemies, at this stage, better justifies the weed's invasion success.

Keywords Interference - Density dependence · In vitro assays - Pot trials - Grassland belt transects . Eragrostis species · Lettuce · Grass ecological response groups 


\section{Introduction}

Campuloclinium macrocephalum (Less.) DC (=Eupatorium macrocephalum Less.), family Asteraceae tribe Eupatorieae, originates from South America (Williams 1976; Cabrera 1978; Breedlove 1986) and has recently become a major invader of roadsides, grassland, savanna and wetland ecosystems in South Africa (Fig. 1a). The plant is a perennial herb that produces several annual stems up to $1.3 \mathrm{~m}$ in height, developing from perennating buds on a woody rootstock below the soil surface. The plant's total biomass places considerable investment in underground structures and during winter all of the living biomass occurs below the soil surface (rootstock and roots), the stems having died off. The root system consists of clusters of thickened tuber-like roots. The common name "pompom weed" is attributed to the puffy pink blossoms borne throughout summer (Fig. 1b). According to the South African Plant Invader Atlas (Henderson 2007), pompom weed may be considered a pioneer species favouring disturbed habitats, with most of the locality records in Gauteng Province $(n=1,337)$ at the time of the study occurring along roadsides. Only 107 (8\%) records were of infestations in adjacent grassland $(n=88)$ or savanna $(n=19)$.

The earliest herbarium record is of a specimen from Johannesburg collected in 1962. More frequent occurrences around Pretoria appeared from the mid 1960s and since then the plant has become conspicuous in grasslands in Gauteng Province, with outbreaks also occurring in surrounding provinces (Henderson 2001). The plant is a declared weed under the South African Conservation of Agricultural Resources Act of 1983, Act 43 of 1983. It remains a mystery as to why, how and when the plant arrived in South Africa. It was never propagated commercially by nurseries; however, there are anecdotal accounts of cut-flowers being sold around Pretoria, presumably from naturalised populations in the wild. We speculate the plant was introduced as a garden ornamental on a small scale or accidentally, e.g. as a contaminant of clothing or cargo. To our knowledge the species has not been cultivated in other countries outside of its native range, nor has it been reported invading other parts of the world.

As with other members of the tribe Eupatorieae that have spread exponentially after naturalisation in
South Africa, e.g. Chromolaena odorata (L.) R. M. King \& Robinson (chromolaena) (Goodall and Erasmus 1996), pompom weed is rapidly expanding its range in grassland and savanna regions since its introduction (Henderson et al. 2003; Henderson 2007). A key difference in the invasion potential of the two species is that chromolaena is frost-sensitive and is restricted to altitudes below $1,000 \mathrm{~m}$, whereas pompom weed occurs from the KwaZulu-Natal coast to the central interior of the Highveld, an altitudinal gradient of ca. $2,000 \mathrm{~m}$. Pompom weed is thus a serious threat to grassland and savanna ecosystems in southern Africa.

Campuloclinium macrocephalum is a densely bristly plant (Fig. 1c). Its trichomes consist of rigid unbranched multicellular hairs and sessile glandular trichomes. Both types occur on the stems, leaves and involucral bracts (Retief 2002). Under magnification both glands and hairs present an unidentified brownish substance and thus, trichomes secreting phototoxic substances may play a role in its invasion success. Such incidences of allelopathy have been cited as being an important trait for successful invasion, the so-called "novel weapons hypothesis" (NWH) (Callaway and Ridenour 2004; Bais et al. 2003). While acknowledging the importance of the absence of natural enemies in invasion biology, those authors proposed that certain invader species are able to transform vegetation because they possess allelochemicals. Under this hypothesis the processes of adaptation allows natural neighbours to cohabit an area with an allelopathic species without suffering negative side effects, but in new environments native species may be intolerant to the same chemical compounds responsible for the allelopathic effect. There could also be neighbourhood effects on overall community composition and structure with weed density expansion.

The "novel weapons hypothesis" is not without contestation. Strong evidence exists refuting the role of (-)-catechin, the phytotoxin principally used in building a case for the NWH as an allelochemical promoting invasiveness of spotted knapweed (Centaurea maculosa Lam.). Blair et al. (2005) found no measurable catechin in soils of spotted knapweed sites using new methods to quantify catechin. Duke et al. $(2009 \mathrm{a}, \mathrm{b})$ refuted the mode of action of catechin causing damage by oxidation, claiming it to be a strong antioxidant that is rapidly denatured by 

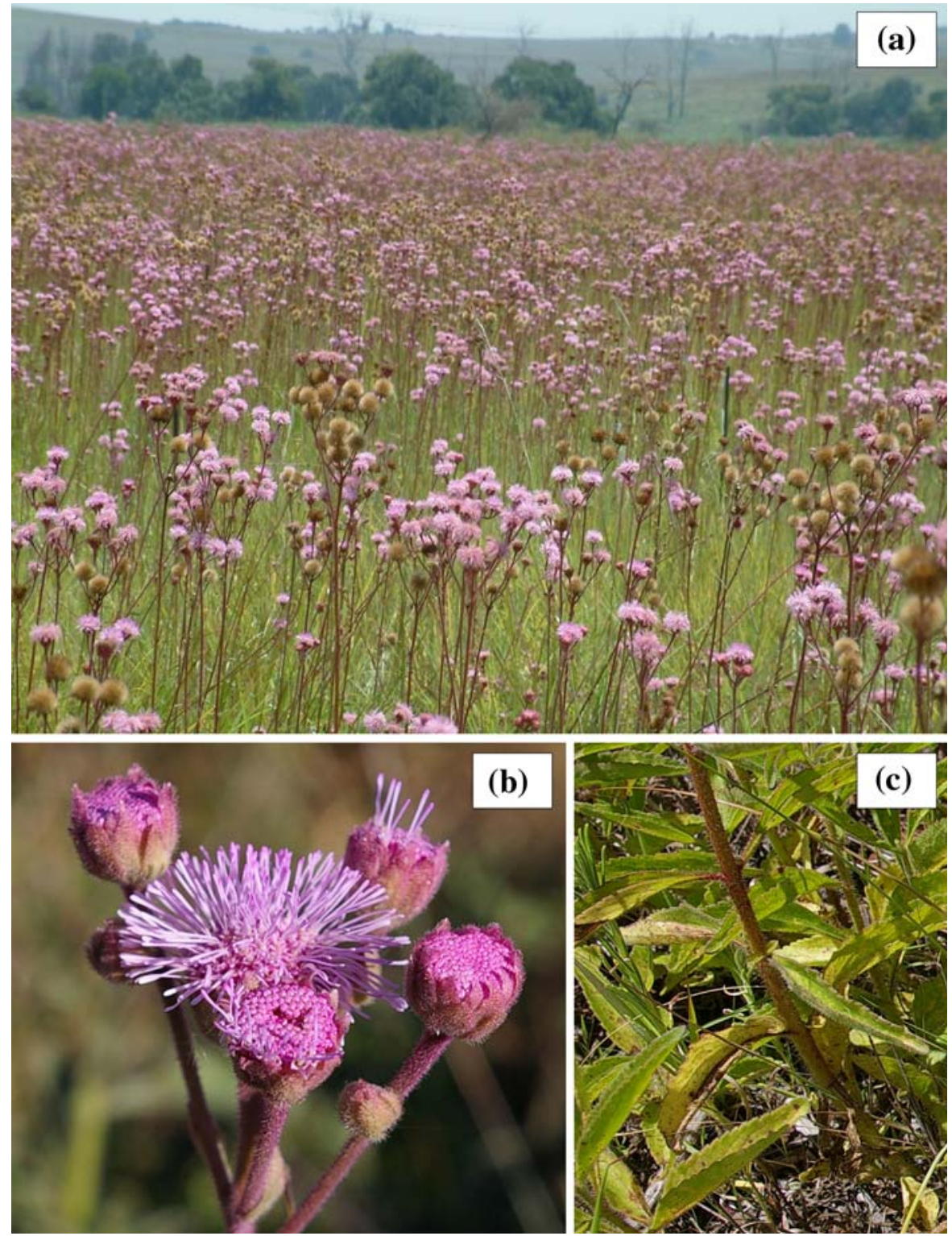

Fig. 1 Campuloclinium macrocephalum (pompom weed) showing (a) an infestation in grassland, and close-ups of (b) flowers and (c) bristly stems and leaves, yellowing due to autumn senescence

extracellular root enzymes. Furthermore these authors showed catechin to be poorly phytotoxic to several plants species in bioassays without soil and in a dose-response experiment in soils from areas where spotted knapweed is found, the lowest dose for a growth reduction was still much higher than that observed in nature.

Harper (1977) refuted the role of allelopathy in plant interactions, calling experiments that testify to allelopathic effects "laboratory artefacts" stating categorically that "any species can, by appropriate digestion, extraction, and concentration, be persuaded to yield a product that is toxic to one species or another." It is now well established that allelopathic effects from laboratory studies should only be accepted if they are supported by field experiments (Stowe 1979; Foy 1999). Under field conditions organic toxins produced by an allelopathic species could be rendered unavailable to neighbouring species or broken down by the combined interactions of 
soil texture, organic matter, temperature, irradiance and microbial breakdown. Most allelopathy experiments fail to take this crucial step of in-field validation. Any studies that claim allelopathy under laboratory conditions are potentially rejecting a true null hypothesis. Hypotheses such as "novel weapons" (Callaway and Ridenour 2004) cannot be supported if the basis for allelopathy hinges on in vitro experimentation involving extracts or leachates alone.

The factors or mechanisms causing or facilitating the invasion of pompom weed into grassland are not yet understood. In this paper the role that allelopathy and competition play in the weed's ability to invade grassland is examined from an ecological perspective. We hypothesize that compounds in pompom weed and/or the weed's competitive ability may affect the germination, growth, survival and recruitment of native grasses and forbs in invaded communities. The findings are presented in three experimental approaches summarised below in the determination of the relative importance of allelopathy and competition in pompom weed.

1. Bioassays (two tests): seeds of test species exposed to pompom weed extracts in vitro in Petri dishes to establish the allelopathic potential of pompom weed on the seed germination and early seedling development of (a) a perennial and an annual grass species and (b) a representative of sensitive broadleaf species.

2. Pot studies (two tests): (a) establish the role of interference in pots by growing pompom weed with the most sensitive species from point one above, and (b) establish the role of crop residues by growing the most sensitive species from point one above in pots containing plant remains.

3. Field investigation: Observe the relation, association and interaction between the frequency and density of pompom weed with the perennial grass species from point one above and grass ecological response groups in Highveld grassland.

\section{Materials and methods}

We chose three test plants for this study. Eragrostis is a dominant genus in grasslands throughout South
Africa, with Eragrostis curvula (Schrad.) Nees (weeping lovegrass) being one of the most common perennial indigenous grass species (Acocks 1953). Seed of a naturally occurring strain (cv. Ermelo) (Rhind 1973) is commercially available making it a popular species for site rehabilitation, reclamation and as a pasture species (Campbell 2000). Both E. curvula and pompom weed favour disturbed roadsides and grasslands (Gibbs Russel et al. 1990; Henderson et al. 2003). Both species are strongly rooted; the fibrous root system of E. curvula is extensive, exploiting soil depths of up to $5 \mathrm{~m}$ (Gomes and Asaeda 2009). In our study E. curvula and pompom weed were found in grassland sites $(n=80)$ with a range of soil types (7-62\% clay), soil $\mathrm{pH}-\mathrm{KCl}(3.78-6.51)$, acid saturation (1-68\%) and soil depths, including sites where plants were growing in exposed subsoil resulting from soil erosion. Eragrostis curvula seed also germinates under high levels of soil sodium (Ryan et al. 1975), making it amenable to a wide variety soil conditions (Foy et al. 1980). Eragrostis curvula was the most sensitive indicator species for interference in biomass production in-field trials involving Parthenium hysterophorus L. (van der Laan et al. 2008).

We propose that E. curvula is a good candidate to test for allelopathy in pompom weed as both species have the potential to be equal competitors under disturbed conditions, but having the ability to use allelochemicals could shift the balance in favour of the phytotoxic species, leading to a reduction in the co-competitor species. This knowledge is not only important in the field of invasion biology but also has financial and ecological implications on commercial rangelands and conservation areas in South Africa. To compliment this we also included an annual grass, E. tef (Zucc.) Trotter, a commercially available noninvasive native of East Africa. Lettuce (Lactuca sativa L.) was selected to represent a sensitive broadleaf species as it is widely used as a test plant in allelopathy experiments (Satoh et al. 1989; Viles and Reese 1996; Junttila 2006).

\section{Bioassays}

Test One: Extracts applied to seeds of Eragrostis species

Aqueous extracts from the roots and shoots of pompom weed were assayed at 1, 10 and $25 \% \mathrm{w} / \mathrm{v}$ 
(fresh weight) for their effects on germination and early seedling development (radicles and coleoptiles) of E. curvula and E. tef. Adult pompom weed plants with roots and shoots intact were harvested from an infestation in Highveld grassland. Roots and shoots of pompom weed were separated and chopped into $10 \mathrm{~mm}$ sections. Root and leafy shoots were weighed separately into $2.5,25$ and $62.5 \mathrm{~g}$ portions and put into flasks containing $250 \mathrm{ml}$ of distilled water to obtain extract concentrations of 1, 10 and $25 \%$ w/v. Flasks were placed in a growth chamber and left to infuse in the dark for $48 \mathrm{~h}$ at $20^{\circ} \mathrm{C}$, then filtered through Whatman No. 1 filter paper (particle retention $11 \mu \mathrm{m}$ ) directly before applying the treatments.

Extracts were tested on certified seed of E. curvula (cv. "Ermelo") and E. tef (cv. "Rooiberg"). Test One comprised 14 treatments consisting of three concentrations $(1,10$ and $25 \% \mathrm{w} / \mathrm{v})$ of root and shoot extracts and a distilled water control on the two Eragrostis species. Seeds were germinated according to the International Seed Testing Association (ISTA) standards. Eragrostis curvula and E. tef were germinated in separate growth chambers at alternating temperatures of $20 / 35^{\circ} \mathrm{C}$ and $20 / 30^{\circ} \mathrm{C}$, respectively, each with an $8 \mathrm{~h}$ day length. "Cool white" fluorescent tubes provided light with a spectral irradiance of $11 \mathrm{Wm}^{-2}$.

Seeds were placed onto two layers of Anchor's seed germination paper circles moistened with extract in Petri dishes ( $9 \mathrm{~cm}$ diameter). Petri dishes were sealed in clear Ziploc plastic bags to maintain optimal moisture conditions and checked every alternate day for signs of desiccation. Germination paper was watered with extract by eyesight and not by volume if visual wetness was below the standard wetness after watering. Standard wetness was obtained by first moistening the filter paper and then holding the Petri dish in a slanting position in order to drain out the excess fluid. The approximate volume to obtain standard wetness on unsoiled (dry) germination paper is about 2-3 ml. Extracts were refrigerated at $5^{\circ} \mathrm{C}$ for the 10 day duration of the experiment after the initial treatment applications.

Each treatment was replicated three times with 50 seeds per replicate. Treatments and replicates were randomised. Radicle and coleoptile lengths of developing seedlings were measured $(\mathrm{mm})$ on two occasions for each species, after 5 and 10 days for $E$. tef and 7 and 10 days for E. curvula. Measured seeds were discarded. The trial was concluded on the 10th day with the second measurement of the remaining seeds of both species. Germinating seeds were also rated for abnormalities such as missing or defective radicles and coleoptiles. Seeds that had not germinated were accepted as dormant, dead or infertile, but lumped into the infertile category due to the difficultly of evaluating viability of small seeds. Data from the 10-day test period was pooled according to species and organs (coleoptiles and radicles).

\section{Test Two: Extracts applied to lettuce seeds (Lactuca sativa)}

Fresh pompom weed material collected in the wild was separated into roots, leaves and flowers. Plant parts were milled fresh and an extraction matrix was prepared with two solvents; water and hexane. Water has a strong polarity, while hexane is non-polar. These widely differing polar properties should result in a wide range of chemicals extracted from the plant material immersed in them. Hexane was used to determine if extract solubility is a factor in the potential allelopathy of pompom weed. The extraction matrix was made up of plant parts and solvents at a standard concentration of $50 \mathrm{~g}$ plant material: $200 \mathrm{ml}$ solvent and allowed to soak for $72 \mathrm{~h}$. Extracts were then centrifuged, filtered through Advantec No. 2 filter paper and diluted 1:10 with ultrapure water in order to ameliorate any inherent toxicity in the solvent. The experiment also included solvent controls, viz. ultrapure water and a 1:10 concentration of hexane in ultrapure water. Seeds were germinated according to the ISTA standards. Extracts were applied to lettuce seeds (cv. Commander) in Petri dishes in the same manner as Test One and germinated in a growth chamber at $15 / 23^{\circ} \mathrm{C}$ with a day length of $12 \mathrm{~h}$. Treatments were replicated three times with 50 seeds per replicate. Treatments and replicates were arranged in a randomised block design. The trial was terminated after 3 days with the measurement of radicle lengths.

\section{Pot studies}

We report on two pot trials, i.e. interference (Test Three) and crop residue (Test Four) studies, following an account of pot preparation and fertigation procedures. The potting medium was a mixture with 
equal quantities by volume of palm peat, vermiculite and potting soil in pots with a diameter and depth of $20 \mathrm{~cm}$. Both experiments were conducted in a tunnel with overhead fertigation. Pots received equal amounts of moisture and nutrients. Pots were watered for $10 \mathrm{~min}$ four times a day between $08 \mathrm{H} 00$ and 15H00. Overhead jets were calibrated to deliver $3 \mathrm{ml} \mathrm{s}^{-1} \mathrm{~m}^{-2}$ nutrient enriched solution at a pressure of $200 \mathrm{kPa}$. Calcium nitrate (N 15.6\%, Ca 21.0\%) was applied twice a week at a rate of $1 \mathrm{~g} \mathrm{l}^{-1}$ with an electrical conductivity (EC) of approximately $120 \mathrm{mS} / \mathrm{m}$. A complete fertilizer (N 5\%, P 4\%, K $20 \%$ plus micro nutrients) (National Plant Foods) especially developed for plants grown in a preenriched composted growing medium was applied thrice weekly at the same rate and EC as calcium nitrate. Calcium and phosphorus were applied separately to avoid a calcium phosphate precipitate. An agricultural disinfectant/plant sanitiser with didecyl dimethyl ammonium chloride $120 \mathrm{~g} \mathrm{l}^{-1}$ was applied twice a week at a rate of $2 \mathrm{ml}$ per $100 \mathrm{l}$ of water to prevent disease. The moisture content of the growing medium could not be determined but plants were healthy and did not show signs of moisture stress or nutrient deficiencies.

\section{Test Three: Interference study}

Eragrostis curvula and pompom weed were grown together in pots to measure the effects of interference (competition + allelopathy) on the dry matter yield of both species. Achenes were collected from C. macrocephalum infestations and refrigerated at $5^{\circ} \mathrm{C}$ for 1 week to break a potential physiological dormancy (Baskin and Baskin 2004). Seeds were then stored under dry ambient conditions at room temperature for 6 months. Achenes with pappus attached were germinated in Petri dishes in a growth chamber at $12 \mathrm{~h} \mathrm{dark} /$ light (spectral irradiance $11 \mathrm{Wm}^{-2}$ ) and $15 / 28^{\circ} \mathrm{C}$, respectively. Germination was first observed after 6 days. Pompom weed seedlings were then transplanted into pots at the two-leaf stage at two densities, one or five plants. Eragrostis curvula cv. Ermelo was sown at a fixed rate of $0.05 \mathrm{~g} / \mathrm{pot}$ $(15 \mathrm{~kg} / \mathrm{ha})$ as the companion species once the pompom weed seedlings had developed to the four-leaf stage $( \pm 1 \mathrm{~cm}$ in height). Five treatments were tested in a simple additive design:
- E. curvula with one or 5 pompom weed $(\mathrm{Cm} 1+\mathrm{Ec} ; \mathrm{Cm} 5+\mathrm{Ec})$ : mixtures.

- E. curvula control (Ec): monoculture.

- Pompom weed controls with one or 5 plants (Cm1; Cm5): monoculture.

Test Three was completely randomised with six replicates per treatment. Plants were harvested after 5 months. Roots of whole plants were placed on a coarse sieve and rinsed under running water to remove growth medium. Plant material was then oven-dried at $80^{\circ} \mathrm{C}$ for 4 days and the dry mass (g; DM) of shoots and roots were recorded separately.

\section{Test Four: Crop residue study}

Eragrostis curvula was grown in potting medium in which pompom weed or E. curvula monocultures had previously been grown to measure the effects of plant remains of both species on the dry matter yield of E. curvula. For this purpose the pompom weed and E. curvula control pots from the interference study (Test Three) were used once these plants had been harvested. Eragrostis curvula cv. Ermelo was the only species tested and was sown at the same rate. The five treatments were:

- E. curvula in medium containing the remains of one and 5 pompom weeds (1R; 5R).

- E. curvula in medium containing the remains of one and 5 pompom weeds plus milled material of one and 5 C. macrocephalum plants (1RM; 5RM).

- E. curvula in medium containing the remains of E. curvula (Control, C).

Upon conclusion of Test Three, oven-dried pompom weed was milled into $1 \mathrm{~mm}$ particles and bagged. Milled material was applied as a layer $10 \mathrm{~mm}$ below the surface of the growing medium at dosages of $15 \mathrm{~g} /$ pot for the single (1RM), and $30 \mathrm{~g} /$ pot for the five weed (5RM) treatments. A delay of approximately 1 week occurred between harvesting plants from Test Three and the start of Test Four. Eragrostis curvula was sown in mid-summer, 1 day after the addition of the milled pompom weed material, and harvested after 4 months when growth had ceased in winter. Eragrostis curvula was ovendried, weighed and analysed in the same manner as Test Three. 
Field investigation

Vegetation assessments were carried out in 80 invaded grassland sites in Gauteng province. Belt transects of $100 \mathrm{~m}$ were laid out in infestations with a weed density ranging from 1 pompom weed per transect to several plants $\mathrm{m}^{-2}$. The spike-point method was used to determine proportional species composition from 200 nearest-to-point plant identifications collected at $0.5 \mathrm{~m}$ intervals along the transect. Pompom weed density per transect was determined by counting rooted plants in 100 contiguous $1 \times 1 \mathrm{~m}$ quadrats.

Native grasses were grouped into ecological response groups according to their response to the intensity and frequency of defoliation (Dyksterhuis 1949; Camp and Hardy 1999), primarily through grazing. The five groups identified consisted of nonresponse (NR), Decreaser (D), Increaser 1 (i1), Increaser 2 (i2) and Increaser 3 (i3) species. Dominant species are parenthesised. Non-response species in this case were grasses that are adapted to growing in soils that are permanently or seasonally waterlogged and are not strongly influenced by grazing (Leersia hexandra Swartz and Imperata cylindrica (L.) Raeuschel). Decreaser species were those that are abundant in grassland in good condition, but decrease when the sward is over or undergrazed (Brachiaria serrata (Thunb.) Stapf, Diheteropogon amplectens (Nees) Clayton and Themeda triandra Forssk.). Increaser 1 dominance is indicative of underutilisation (Hyparrhenia hirta (L.) Stapf, Schizachyrium sanguineum (Retz.) Alst. and Trachypogon spicatus (L. f.) Kuntze). Increaser 2 dominance is caused by sustained overgrazing (Cynodon dactylon (L.) Pers., E. curvula and Heteropogon contortus (L.) Roem. \& Schult.) and Increaser 3 species dominate under sustained selective grazing pressure (Aristida junciformis Trin. \& Rupr., Elionurus muticus (Spreng.) Kunth and Sporobolus africanus (Poir.) Robyns \& Tournay). We report on the interactions between pompom weed, Eragrostis curvula and grass ecological response groups.

Data analysis

Trials involving Petri dishes (Bioassays) and pots (Pot Studies) had randomised block designs. Data from these experiments were subjected to analysis of variance (ANOVA) followed by Tukey post hoc tests for means $(\alpha=0.05)$. Data from vegetation assessments were summarised using regressions and simple charting. The computer software used for the analyses were Statistica 6.1 (StatSoft Inc. 2004) and Blossom version W2005 for the quantile regressions (Cade and Richards 2005).

\section{Results}

Bioassays

Test One: Extracts applied to seeds of Eragrostis species

Differences in germination percentages occurred between extracts in the E. curvula test; however, none of the treatments were significantly different to the control $(P>0.207)$. Germination inhibition did not occur in E. tef $(P=0.105)$. Both species produced germination rates above $80 \%$ in all treatments, well above the $70 \%$ minimum permissible for commercial seed (ISTA rules). Radicles of both E. curvula and E. tef were more sensitive than coleoptiles to extracts; the latter were not significantly different from the control treatments. Root extracts had a negligible effect on radicle size and appeared to have stimulated their growth (Fig. 2), but this effect was not significant. Shoot extracts had a detrimental effect on radicle size, aggravated by increasing extract concentrations. In E. curvula significant radicle-stunting was produced by both $10 \%$ and $25 \%$ shoot extracts $(P<0.01)$. Radicle stunting only occurred in the $25 \%$ shoot extract treatment in E. tef $(P=0.017)$.

Relative tolerances of E. curvula and E. tef to extracts were compared after transforming radicle and coleoptile data into incremental values (treatment-control); where E. curvula and E. tef controls both equal zero for their respective treatments (Fig. 3). Treatment by species interactions were significant for radicles $\left(F_{(6,28)}=4.23, P=0.004\right)$ but not for coleoptiles $(P=0.051)$. The $25 \%$ shoot extract was the only treatment that produced differences between the two species, with E. curvula producing smaller radicles $(P<0.001)$ than $E$. tef.

Seedling abnormalities were detected but there was no significant difference between species. Main 


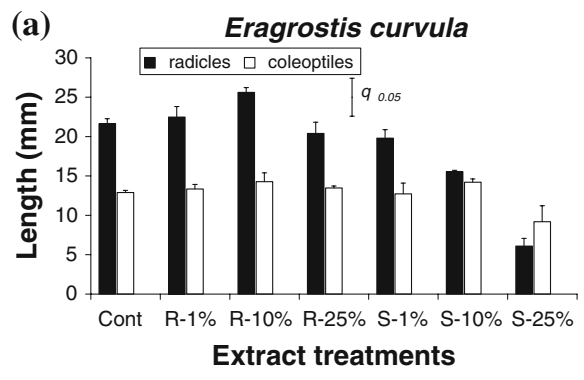

Fig. 2 Growth of radicles and coleoptiles of (a) Eragrostis curvula and (b) E. tef after 10 days exposure to three aqueous extract concentrations $(1,10$ and $25 \%$ ) from the roots (R) and leafy shoots (S) of Campuloclinium macrocephalum. Eragrostis species are presented separately because (a) E. curvula was

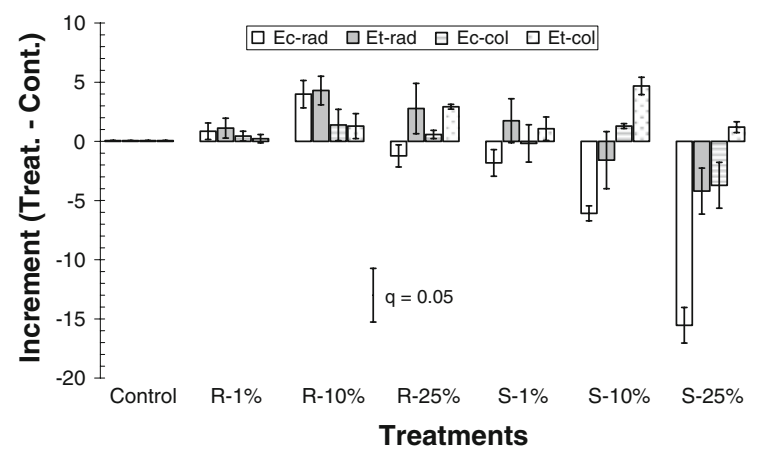

Fig. 3 Relative tolerance (mean $\pm \mathrm{SE}$ ) of germinating radicles (rad) and coleoptiles (col) of Eragrostis curvula (Ec) and E. tef (Et) seeds that were exposed to three concentrations (1, 10 and $25 \%$ ) of aqueous extracts from the roots (R) and shoots (S) of Campuloclinium macrocephalum. Increment was used to measure and compare relative tolerance by subtracting the mean control size $(\mathrm{mm})$ from mean treatment size $(\mathrm{mm})$ in radicle and shoot categories in each replicate. The critical range $q(\alpha=0.05, v=28, k=7)$ is applicable for all groups in the legend

abnormalities included missing radicles, defective radicles and coleoptiles and spindly seedlings. The greatest incidence of abnormalities, 49.4 and $75 \%$, occurred in the 10 and $25 \% \mathrm{w} / \mathrm{v}$ shoot extracts, respectively $\left(F_{(6,28)}=12.34, P<0.001\right)$, while the remaining treatments were not significantly different from the distilled water control.

\section{Test Two: Extracts applied to lettuce seeds (Lactuca sativa)}

Interactions between solvents (hexane, water) and plant tissues were not responsible for eliciting significant differences in the germination or radicle

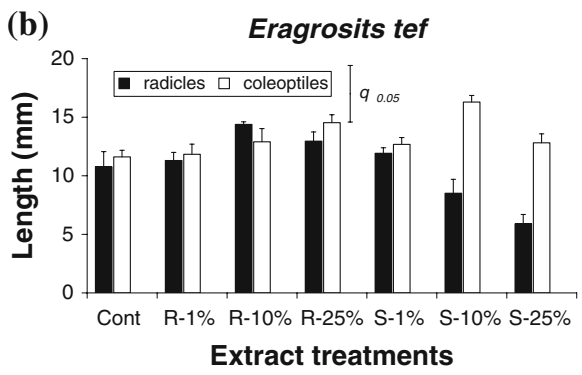

grown under temperatures of $20 / 35^{\circ} \mathrm{C}$ while (b) E. tef was grown at $20 / 30^{\circ} \mathrm{C}$. Means are presented with their respective standard errors and the critical range $q$ of the Tukey post hoc test $(\alpha=0.05, v=14, k=7)(\operatorname{Zar} 2003)$

development of lettuce seeds. The average germination percentage was $90.4 \%$, with the distilled water control achieving a maximum of $96.6 \%$ and the hexane control a minimum of $80.6 \%$. The largest mean radicle size was observed in root extract in water but was not significantly larger than the smallest radicles emerging from the leaf extract in water. Flower, root, and to a lesser extent leaf extracts, in hexane and water had little effect on germination and root elongation of lettuce seeds at the concentrations tested. Water soluble and insoluble extracts from the below and/or ground structures of pompom weed do not appear to be inhibitory to the germination and early seedling development of lettuce.

At this juncture it is not certain what extract concentration of pompom weed may be realistic to reflect an allelopathic effect in nature. Pot trials using the most sensitive indicator species, in this instance E. curvula, were carried out to determine whether potential allelopathy from the pompom weed extracts was repeated under more natural conditions by growing both species together with nutrient supplementation.

Pot studies

\section{Test Three: Interference study}

Pompom weed grown at one or five plants per pot and planted with E. curvula at a fixed sowing rate did not affect the DM yield of roots or shoots of the latter (Fig. 4). The yield of pompom weed roots $\left(F_{(3,20)}=19.45, P<0.001\right)$ and shoots $(F=6.66$, 


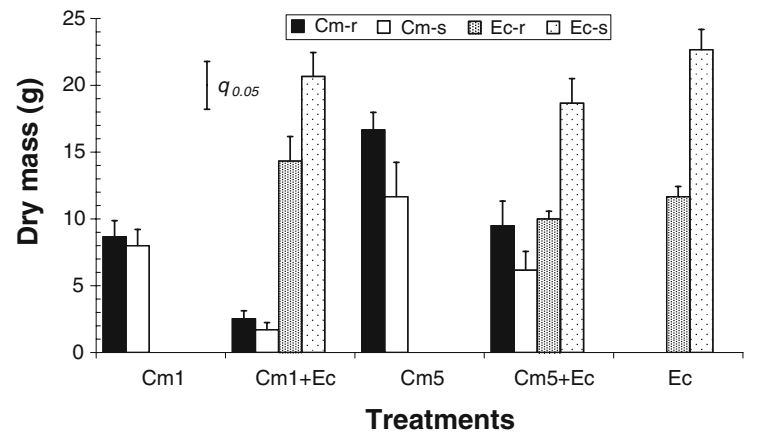

Fig. 4 The effect of intra and interspecific interference on the dry matter yields (mean \pm SE) of roots (-r) and shoots (-s) of Campuloclinium macrocephalum $(\mathrm{Cm})$ and Eragrostis curvula (Ec) in pots at 5 months after planting. Campuloclinium macrocephalum was planted one $(\mathrm{Cm} 1)$ and five plants (Cm5) per pot, with and without E. curvula sown at a rate of $0.05 \mathrm{~g}$ per pot. The treatments $\mathrm{Cm} 1, \mathrm{Cm} 5$ and $\mathrm{Ec}$ are pure stands of weed and grass, respectively. The critical range $q$ $(\alpha=0.05, v=20, k=4)$ is only applicable for weed root $(\mathrm{Cm}-\mathrm{r})$ and shoot (Cm-s) groups. Eragrostis curvula root and shoot yields were not significantly different $(\alpha=0.05, v=20$, $k=3$ )

$P=0.003)$ when planted with $E$. curvula differed significantly. Grass interference reduced root and shoot production of pompom weed by $75 \%$ in $\mathrm{Cm} 1+\mathrm{Ec}$ and $45 \%$ in $\mathrm{Cm} 5+\mathrm{Ec}$. The 5-plant control (Cm5) collectively produced almost double the root DM of the single plant treatment $(\mathrm{Cm} 1)(P=0.002)$. Shoot yields between the two pompom weed controls was not significantly different $(P=0.392)$ but total $\mathrm{DM}$ was $70 \%$ greater in the 5-plant treatment $(P=0.010)$. Mixtures followed a similar pattern. Pompom weed died in one replicate of the $\mathrm{Cm} 1+\mathrm{Ec}$ treatment (17\% mortality) and its remains at the time of harvesting were one-tenth the size of the other samples in treatment. Variation in the type (intra vs. interspecific) and intensity (plant density) of interference had little affect on resource allocation, i.e. rootshoot ratios, in either pompom weed $(P=0.513)$ or E. curvula $(P=0.133)$. This suggests a history of independent adaptation of both species to plant community competition on separate continents. The ability of both species to coexist in a confined growing space offers little evidence to support phytotoxicity in either species.

Relative interference on net pompom weed production from intraspecific, interspecific and absolute competition (total biomass $=$ pompom weed + E. curvula) was determined by comparing the mean

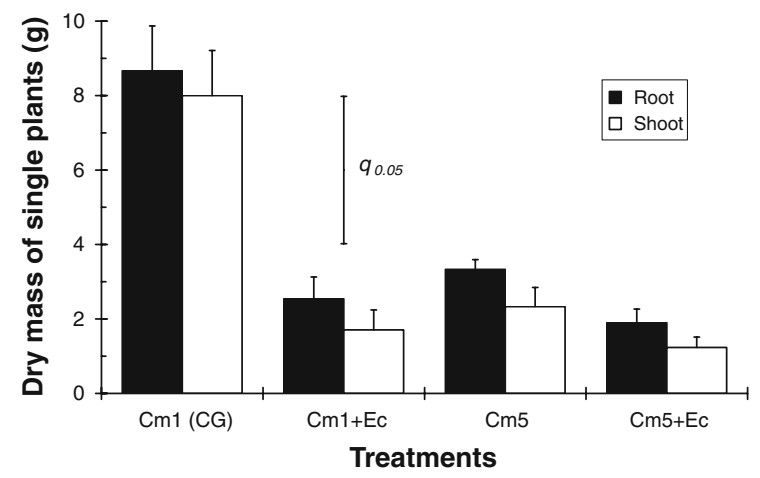

Fig. 5 The effect of intra and interspecific interference on the dry matter yields of individual Campuloclinium macrocephalum grown at one $(\mathrm{Cm} 1)$ or $5(\mathrm{Cm} 5)$ plants per pot, with or without Eragrostis curvula (Ec). Values are represented as means with their respective standard errors and the critical range $q(\alpha=0.05, v=20, k=4)$. The control group (CG) is significantly different to all the other treatments

weights of pompom weed individuals (Fig. 5). Intraspecific interference $(\mathrm{Cm} 5)$ reduced root and shoot dry matter yields by 62 and $71 \%$ respectively. Combined intra- and interspecific (with E. curvula) interference caused a 78-85\% reduction in pompom weed root and shoot DM. Significant differences were detected between root $\left(F_{(3,20)}=19.22, P<0.001\right)$ and shoot yields $\left(F_{(3,20)}=19.0, P<0.001\right)$. Roots and shoots of $\mathrm{Cm} 1$ (control group) were significantly heavier than those of individual plants in all the other treatments with pompom weed.

Total biomass DM (roots + shoots), i.e. all plant species per pot, varied significantly $\left(F_{(4,25)}=14.28\right.$, $P<0.001$ ) between treatments (Fig. 6). A difference of $70 \%$ in weed biomass between single and the 5-plant controls (Cm1, Cm5) was considered statistically not significant $(P=0.052)$, however, $\mathrm{Cm} 1$ had significantly less biomass than the remaining treatments $(\mathrm{P} \leq 0.01)$. The grass control $(\mathrm{Ec})$ only produced significantly more dry mass than $\mathrm{Cm} 1(\mathrm{P}=$ 0.002). These results indicate that young pompom weed plants are more sensitive to inter- and intraspecific interference than is E. curvula, which showed negligible modulation at differing pompom weed densities (zero, one and 5 plants/pot). The potential of increased amounts of phytotoxins onto the companion species with increasing pompom weed density was not apparent. Pompom weed densities of one and 5 plants/pot is equivalent to 32 and 159 plants $\mathrm{m}^{-2}$ which is 5 and 25 times larger than the observed 


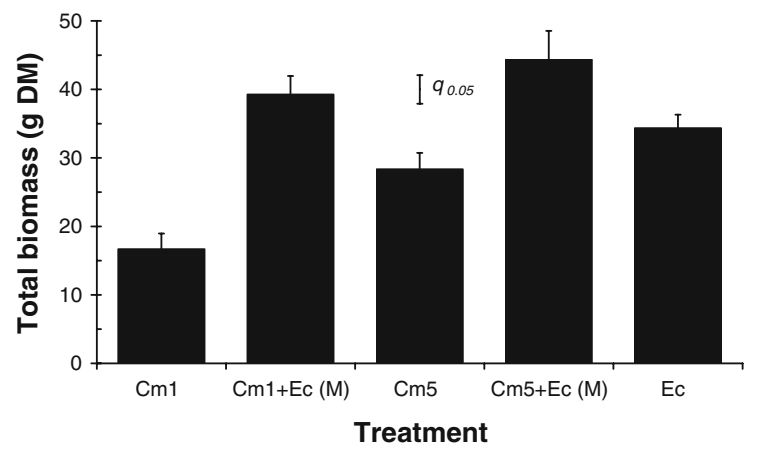

Fig. 6 The effect of intra and interspecific interference on the total biomass for all plant species per pot, with or without, Campuloclinium macrocephalum at one $(\mathrm{Cm} 1)$ or $5(\mathrm{Cm} 5)$ plants per pot and the test species Eragrostis curvula (Ec) sowed at a rate of $0.05 \mathrm{~g}$ per pot. Mixtures are denoted by the letter $M$ in brackets. Means are presented with their respective standard errors and the critical range $q(\alpha=0.05, v=25$, $k=5$ )

maximum density in the field. Thus the question of what extract concentration may be realistic to reflect an allelopathic effect in nature may now not be relevant. Pompom weed was not allelopathic to E. curvula, the most sensitive bioassay indicator species, when both species occupied the same growing space and shared root and shoot contact; unless allelochemicals increase in quantity and/or potency with age.

\section{Test Four: Crop residue study}

Pots containing plant remains from monocultures of pompom weed and E. curvula grown in Test Three did not have a significant effect on yield of E. curvula roots, shoots and plant numbers (Fig. 7). Pompom weed density (1R and 5R) did not have a significant impact on E. curvula roots $(P=0.071)$ and shoots $(P=0.077)$. The incorporation of milled pompom weed (1RM and 5RM) appeared to have mitigated the effects of the pompom weed remains on E. curvula production in the high density pompom weed treatment (5R), but the effect was not significant $(P=0.078)$. Pompom weed remains were therefore no more allelopathic than those of E. curvula.

\section{Field investigation}

Pompom weed was present at variable densities in all of the 80 grassland sites sampled but E. curvula was present in only 67 sites. The relationship between

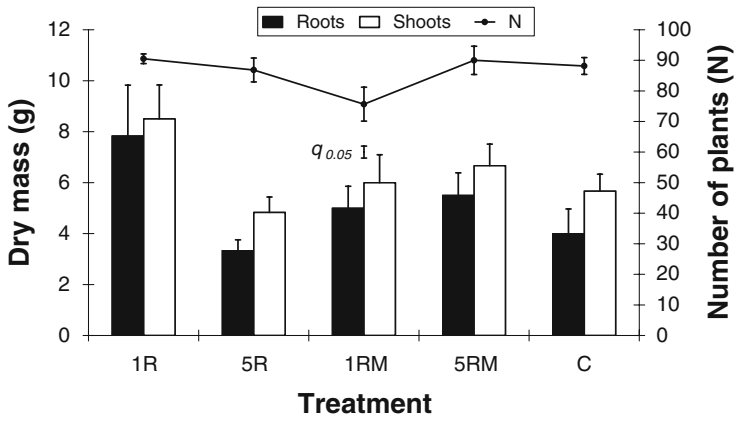

Fig. 7 The effect of Campuloclinium macrocephalum residues (R), C. macrocephalum remains plus dried milled plants (RM) at planting densities of one or five plants per pot and Eragrostis curvula remains (Control-C) on the biomass production of Eragrostis curvula four months after sowing at a fixed rate of $0.05 \mathrm{~g} /$ pot. Dry matter yields of E. curvula (bars) roots and shoots are presented on the first $y$-axis. The number of E. curvula plants (line) in pots is presented on the second $y$-axis. Means are presented with their respective standard errors. The critical range $q(\alpha=0.05, v=25, k=4)$ applies to all groups in the legend (Wilks $\lambda=0.514, F_{(12,61)}=1.457$, $P=0.166)$

pompom weed frequency (\%) and pompom weed density $\left(\mathrm{m}^{2}\right)$ based on sites with E. curvula was significant (Fig. 8). Pompom weed density increased at a rate of 1.5 plants $\mathrm{m}^{-2}$ with each $10 \%$ increase in pompom weed frequency. Maximum pompom weed frequency and density at sites where E. curvula was present were $46 \%$ and 6.4 plants $\mathrm{m}^{-2}$, with a mean pompom weed frequency and density of $7.5 \%$ and 1.3 plants $\mathrm{m}^{-2}$ respectively. These data pertain to pompom weed only.

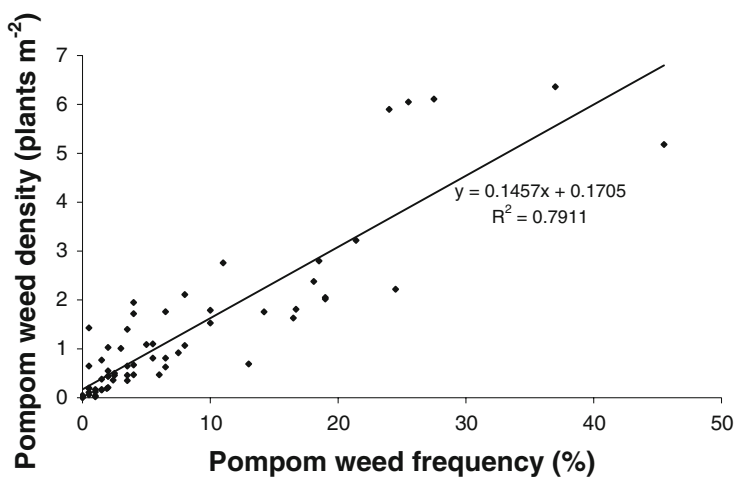

Fig. 8 The relationship between pompom weed (Campuloclinium macrocephalum) frequency $(\%)$ and density $\left(\mathrm{m}^{-2}\right)$ in 67 belt transects at sites with Eragrostis curvula in Gauteng Province, South Africa (regression summary: $r=0.889$, $\left.r^{2}=0.791, t=15.69, P<0.001\right)$ 
The linear association between the percentage frequencies of E. curvula ( $x$-axis) and pompom weed ( $y$-axis) was judged to be significant $(P=0.015)$ (Fig. 9) but the correlation coefficients were weak ( $r=-0.297, r^{2}=0.088$ ) due to heteroscedasticity. Least absolute deviation (LAD) or quantile regression was more appropriate at explaining the response of pompom weed to the limiting function of E. curvula frequency at the 90th quantile (Fig. 9). Eragrostis curvula at low frequencies of $0.5-5 \%$ appeared to reduce pompom weed frequency by halving it from $40 \%$ (6 plants $\mathrm{m}^{-2}$ ) to $20 \%$ (3.1 plants $\left.\mathrm{m}^{-2}\right)$. An abrupt change in the pattern of the relationship occurred above $5 \%$ E. curvula frequency and the trend flattened, resulting in the next halving of pompom weed from 20 to $10 \%$ at E. curvula frequencies of $40-50 \%$, an increase of $45 \%$ in the occurrence of E. curvula. At the highest observed frequency of $67 \%$ E. curvula seemingly imposed a maximum limitation on pompom weed frequency of $9 \%$ (1.5 plants $\left.\mathrm{m}^{-2}\right)$, which was not much different to the weed's frequency at E. curvula frequencies above $30 \%$, and still a considerable weed density when extrapolated to 15,000 plants ha ${ }^{-1}$. This indicated a high degree of coexistence between E. curvula and pompom weed.

The notion of low competing plant abundance of one species (E. curvula) causing fundamental reductions in the populations of a second species (pompom weed), but not when the first species is at higher

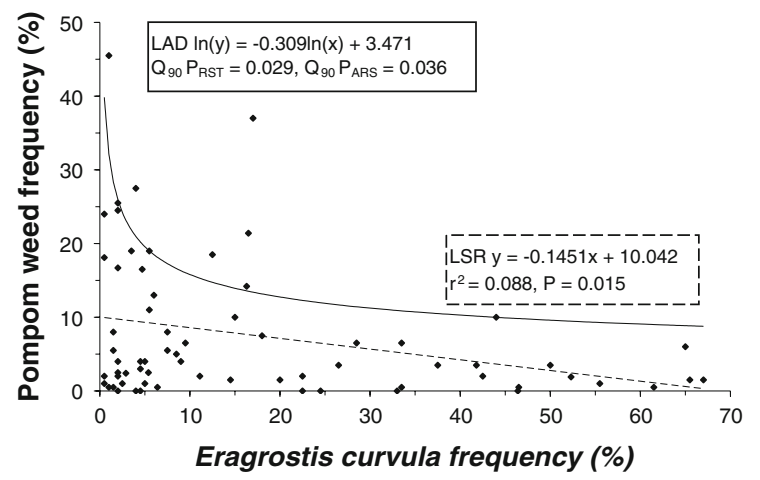

Fig. 9 The relationship between Eragrostis curvula and pompom weed frequencies in belt transects from 67 grassland sites in Gauteng Province. The lines depict different regression models applied to frequency data; viz. least squares regression $(L S R)$ dashed line and quantile regression (LAD) solid line where $\mathrm{Q}_{90}$ is the 90th quantile of log-transformed data $\left(P\right.$-values: $P_{\mathrm{RST}}=$ Rank Score Test Statistic, $P_{\mathrm{ARS}}=$ Asymptotic Rank Score Statistic) levels of abundance (Fig. 9) is somewhat contrary to the concept of density-dependant interspecific competition. In the LAD model $90 \%$ of the pompom weed frequency values ( $y$-axis) were less than or equal to the function of E. curvula. In essence E. curvula was a surrogate for the unmeasured factors limiting at many sites (Cade and Noon 2003). Furthermore, no association was detected between pompom weed and E. curvula using contingency tables $\left(\chi^{2}=1.37, d f=1, P=0.242\right)$.

Landuse management at the 80 grassland sites was summarised into three categories, unutilised land (54\%), rangeland for grazing $(41 \%)$ and abandoned fields or old-field successions (5\%). The majority of sites were not grazed (59\%) and 39\% experienced under or selective grazing pressure. Overgrazing did not occur at sites with zero to $0.5 \%$ E. curvula, based on the indicator species present (Fig. 10). Sites where E. curvula was virtually absent had the greatest incidence of seasonal flooding or inundation (54\%).

Rather than being suppressed by pompom weed, sites with zero E. curvula (Fig. 10), an i2 species, were dominated by the grass ecological groups NR (dominant in wetlands), D (well managed grassland) and i1 (moribund grassland). Those groups would have offered little niche opportunity for E. curvula to establish. Pompom weed $\left(\mathrm{CM}^{*}\right)$ and contributions of the NR-D-i1 group mosaic declined proportionately with increasing E. curvula. Wetland grasses (NR

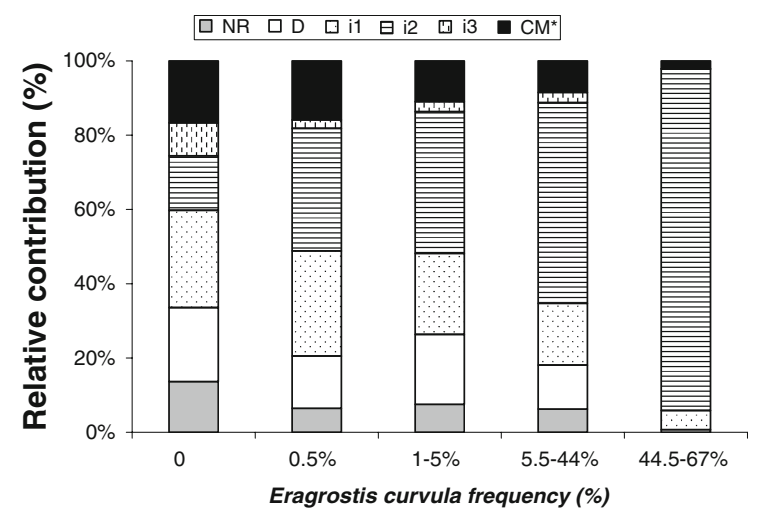

Fig. 10 The relative contribution of grass ecological groups and pompom weed to grassland composition in sites along a gradient of increasing Eragrostis curvula dominance (an Increaser 2 species), as predicted by quantile regression at the 90th quantile $(P=0.03$; Fig. 9$)$. Group acronyms stand for: non-responsive (NR), decreaser (D), increaser (i1, i2, i3) and pompom weed $\left(\mathrm{CM}^{*}\right)$. See "Materials and methods" for more details 
species) and E. curvula had opposite soil moisture and drainage requirements, the former being absent in sites with more than $34 \%$ E. curvula, the latter only achieving dominance in sites without NR species. Decreaser species were under represented in all E. curvula frequency categories suggesting selective grazing or poor management in the past was largely responsible for their reduction. These rangelands could have been abandoned due to deteriorating carrying capacity, based on the evidence that most sites are presently not utilised. Poor drainage, high soil moisture and to a lesser extent grazing management had more to do with limiting the abundance of E. curvula in some sites than the abundance of pompom weed.

\section{Discussion}

Asteraceous weeds are notorious at producing compounds that kill or suppress neighbouring species under artificial conditions. For example, P. hysterophorus (parthenium) contains sesquiterpene lactones, an important group of compounds involved in allelopathy (Reinhardt et al. 2004). Leaf extracts of this weed are apparently strongly phytotoxic to plants, inhibiting germination and affecting seedling development of several broadleaf and grass species (Adkins and Sowerby 1996; Tefera 2002) at concentrations ranging from 6 to $25 \%$ w/v. Reinhardt et al. (2004) in sequestering parthenin from parthenium found trichomes harvested on both leaf surfaces contained almost $100 \%$ parthenin but stems and roots contained only trace amounts of the substance. The water solubility of parthenin was reported as being low and in this regard, active compounds accumulated in trichomes of C. macrocephalum may have remained insoluble in the aqueous extracts, thereby reducing their allelopathic effect on Eragrostis (Test One). In our study, extracts of $C$. macrocephalum exhibited mild allelopathy on Eragrostis species at 10 and $25 \%$ concentrations by stunting radicles, but produced no detectable phytotoxic activity causing germination inhibition and coleoptile abnormalities. At similar concentrations parthenium had a great impact on seed germination and plant growth, regardless of the solubility of parthenin. On the other hand, water insoluble compounds from pompom weed tissues in hexane did not cause a reaction in the germination of lettuce either.
Significant variation in the sesquiterpene chemistry of $P$. hysterophorus has been reported from populations sampled from various regions of its worldwide distribution (Picman and Towers 1982), but this should not account for the discrepancies in magnitude of allelopathy between laboratory and field studies involving parthenium extracts. Pure parthenin was considered a weak germination inhibitor (Belz et al. 2007) of several African grass species under natural conditions, including E. curvula (van der Laan et al. 2008). In spite of parthenium displaying strong laboratory allelopathy (Adkins and Sowerby 1996; Tefera 2002), Belz et al. (2009) discovered that parthenin is not sufficiently persistent, phytotoxic, or bioavailable in natural soils "to cause an allelopathic effect that could contribute to the invasiveness of parthenium." Given the invasiveness of parthenium under soil and environmental conditions favouring the degradation of parthenin, Belz et al. (2009) speculated that self-stimulatory allelopathy rather than inhibitory allelopathic interactions may assist the species in forming dense monotypic stands.

In our study E. curvula was a more sensitive indicator species of allelopathy than E. tef, confirmed by studies on parthenium on a range of native perennial grass species (van der Laan et al. 2008). Results from in vitro experiments were not convincing when one considers extracts did not inhibit germination in any of the test species and rootstunting of E. curvula was not repeated in the pot trials. This would imply that the extracts tested were more concentrated in the in vitro assays than natural levels of allelochemicals in the weed. In addition to parthenium, sufficient evidence exists in the Asteraceae alone of species that produce plant-chemical interactions in laboratory experiments failing to do so under natural conditions. In a similar vein to the rejection of the NWH based on the properties of spotted knapweed (Duke et al. 2009a, b); Ito et al. (1998) found that the allelochemical dehydromatricaria ester (DME) produced by Solidago altissima L. inhibited seedling development in rice in both agar and soil cultures. The inability to detect DME in soil water in natural stands; however, led them to conclude that S. altissimo has little allelopathic activity in the field. The allelopathic effects of chromolaena in laboratory studies (Hoque et al. 2003) is not repeated under natural conditions, where 
it is an important species in fallow-cropping systems in Africa and Asia (Roder et al. 1995; Koutika et al. 2002; Ikuenobe and Anoliefo 2003) and is perceived amongst farmers to be a beneficial plant rather than a noxious weed.

The relative importance of plant age, phytotoxicity and competition could not be determined because neither pompom weed density nor allelopathy had a strong impact on companion species in the interference study (Test Three). The only positive allelopathic result involved Petri-dish bioassays of leaf extracts on E. tef and E. curvula from adult pompom weed (Test One). In the interference and crop residue experiments (Tests Three and Four), conducted under more natural conditions in pots, young pompom weed plants or remains were not allelopathic to E. curvula at densities far higher than the maximum observed field density of 6.4 plants $\mathrm{m}^{2}(=0.2$ plants/pot). In a field trial investigating interference between parthenium and three common grass species in South Africa, E. curvula consistently produced the lowest biomass over two growing seasons at parthenium densities of 5 and 7.5 plants $\mathrm{m}^{-2}$ (van der Laan et al. 2008). More importantly, parthenium density did not influence the biomass of E. curvula significantly. In our study there was no indication of phytotoxicity, neither was the growth of E. curvula affected by pompom weed density. Nevertheless, having survived at populations (plants $\mathrm{m}^{-2}$ ) 25 times the observed maximum naturalised density (Fig. 8), pompom weed has exhibited an extraordinary tolerance to intense competition at early establishment. This provides an indication of coexistence but the relative importance of above and below ground organs on interference requires additional investigation.

The degree of allelopathy increasing with age could simply be a function of increasing biomass (Koricheva 1999) and in the case of pompom weed, the quantity of glandular trichomes responsible for producing the toxin. In contrast, the ability to exert an allelopathic influence soon after germination would be an advantage in aiding early establishment and release from neighbourhood competition (Kruse et al. 2000). For example, Wardle et al. (2006) discovered that aqueous extracts and leachates of the Asteraceous biennial Carduus nutans L. (nodding thistle) were more allelopathic on grasses and legumes at the rosette stage (young plants) than adults. An association between pompom weed and E. curvula was not apparent in the field investigation, confirming the "not allelopathic" outcome of the interference experiment (Test Three) and making it unlikely that plant age is a factor in the potential allelopathy of pompom weed.

Symbiosis was not apparent between pompom weed and Eragrostis curvula. Pompom weed's ecological niche is broader than that of E. curvula but the niche overlap between these species appears to be quite wide, both species preferring disturbed conditions. Pompom weed exhibits a greater degree of adaptive plasticity by invading a wider range of soil types, soil moisture gradients and disturbance regimes. Eragrostis curvula is adapted to disturbed sites on well drained soils (van Oudtshoorn 2006), being largely absent in wetlands (Kotze and O'Connor 2004) and grasslands that are moribund or underutilised (Goodall 2000). Where one of these species was more dominant it usually implied site conditions precluded the other and had no bearing on the competitive superiority of one over the other. Interference studies in pots and in-field studies measuring intraspecific interference were mutually conclusive; E. curvula at high densities limits dominance of $C$. macrocephalum, but does not exclude pompom weed establishment. Coexistence might involve a trade-off of size for survival and reproduction in pompom weed where landuse favours the dominance of E. curvula. Two hypotheses could provide plausible alternatives for its invasion ecology. The ability of pompom weed to survive and reproduce under intense $E$. curvula competition may involve sourcing unidentified limiting resources not utilised by the grass (Tilman 1985). Alternatively, being predator-free and disease-free, could provide pompom weed the advantage of being able to withstand degrees of interspecific competition from native communities in the introduced range (Huffaker et al. 1976). In this study the pot trials and field investigation collectively support the conclusion that both species are excellent competitors which are able to coexist rather than be competitively exclusive in vegetation they both occupy.

Thorpe et al. (2009) discovered from field experiments on two continents that some species in the introduced range of the controversial forb Centaurea maculosa Lam. (Callaway and Ridenour 2004; Bais et al. 2003; Blair et al. 2005; Duke et al. 2009a, b) 
had reduced growth compared with co-occurring species in its native range which did not. This implied a level of adaptation in plant communities to phytotoxic compounds in the alleged allelopathic species through shared evolutionary history, which was absent in the introduced range. In this context adaptation and coexistence could be possible if pompom weed was allelopathic and E. curvula had evolved defence mechanisms against them. Laboratory studies on Eragrostis and lettuce revealed "evolved" defences were weakest in E. curvula but interference experiments refuted the role of allelopathy in $C$. macrocephalum. The novel weapons hypothesis in this case did not apply to pompom weed.

We acknowledge the difficulties of separating allelopathic interference from other forms of interference. Under laboratory conditions parthenium may be considered far more allelopathic than pompom weed, and yet under field conditions parthenium has been proven to not be allelopathic (van der Laan et al. 2008; Belz et al. 2009). Stowe (1979) remarked that bioassays do not simulate natural conditions, and if studied in isolation the investigator is left unable to accept or reject allelopathy from a positive or negative result. Under field conditions phytotoxic compounds produced by plants are rapidly degraded in the soil to the extent where they are biologically unavailable to produce plant-plant interactions (Harper 1977; Schmidt and Ley 1999). The identification of chemicals produced by plants aiding in their defence against neighbourhood competition, predation and disease is a crucial step in proving the existence of "novel weapons". The compounds produced by pompom weed trichomes have not been described and so the question what constitutes a natural concentration that cause an allelopathic effect cannot be answered until we know more about the chemistry of this species. Proving allelopathy is a daunting endeavour (Romeo 2000; Duke et al. 2009b) because the onus is on researches not only to identify the chemical structures but to also use ecologically relevant species, and demonstrate the production and movement of phytotoxin from the donor plant to the receiving plant growing in the same soil, which in itself is a complex substrate.

We conclude that allelopathy does not appear to be a major factor for the invasiveness of pompom weed in the grassland biome based on ecological evidence.
Other site-based factors, multivariate in nature, are likely to govern the density of pompom weed and its association with, or impact on, other species. Secretions from glandular trichomes on the leaves may have alternative properties such as anti-fungal or as a defence against herbivory (antifeedant). Biochemical studies on pompom weed are an urgent priority. This raises the question as to which hypothesis best fits the success of $C$. macrocephalum as an invasive alien species. Based on the evidence presented here, the absence of natural enemies and or niche differentiation along resource gradients carries more weight than $C$. macrocephalum being a phytotoxic species.

Acknowledgments $\mathrm{We}$ are grateful to the following organisation and people for which this study would not otherwise have been possible. This study was funded by the Gauteng Department of Agriculture, Conservation and Environment (GDACE). Derrick Nkala and Lynette Khumalo helped with the running of the allelopathy experiments and pot trials. Lesley Henderson (ARC-PPRI) provided the localities of the grassland sites used in the study from the South African Plant Invaders Atlas (SAPIA). Dr Pieter Pieterse and students from Pretoria University assisted with vegetation assessments. Craig Morris (ARC-RFI) assisted with statistical analyses. We thank Profs Dave Mycock and Marcus Byrne (Wits University) for comments on earlier drafts. The authors are greatly appreciative of the comments and suggestions of the anonymous reviewers, which have improved the paper considerably.

\section{References}

Acocks JPH (1953) Veld types of South Africa. Botanical Survey Memoir No. 28. The Government Printer, Pretoria

Adkins SW, Sowerby MS (1996) Allelopathic potential of the weed. Parthenium hysterophorus L., in Australia. Plant Prot Q 11:20-23

Bais HP, Vepachedu R, Gilroy S, Callaway RM, Vivanco JM (2003) Allelopathy and exotic plant invasion: from molecules and genes to species interactions. Science 301: 1377-1380

Baskin JM, Baskin CC (2004) A classification system for seed dormancy. Seed Sci Res 14:1-16

Belz RG, Reinhardt CF, Foxcroft LC, Hurle K (2007) Residue allelopathy in Parthenium hysterophorus L.-does parthenin have a leading role? Crop Prot 26:237-245

Belz RG, van der Laan M, Reinhardt CF, Hurle K (2009) Soil degradation of parthenin-does it contradict the role of allelopathy in the invasive weed Parthenium hysterophorus L.? J Chem Ecol 35:1137-1150

Blair AC, Hanson BD, Brunk GR, Marrs RA, Westra P, Nissen SJ, Hufbauer RA (2005) New techniques and findings in the study of a candidate allelochemical implicated in invasion success. Ecol Lett 8:1039-1047

Breedlove DE (1986) Flora de Chiapas. Listados Florísticos de México 4:1-246 
Cabrera AL (1978) Compositae. Flora de la provincia de Jujuy $10: 1-726$

Cade BS, Noon BR (2003) A gentle introduction to quantile regression for ecologists. Front Ecol Environ 1:412-420

Cade BS, Richards JD (2005) User manual for Blossom statistical software. Fort Collins Science Center, U.S. Geological Survey, Fort Collins

Callaway RM, Ridenour WM (2004) Novel weapons: a biochemically based hypothesis for invasive success and the evolution of increased competitive ability. Front Ecol Environ 2:436-443

Camp KGT, Hardy MB (1999) Veld condition assessment. In: Hardy MB, Hurt CR (eds) Veld in KwaZulu-Natal. KwaZulu-Natal Department of Agriculture, Pietermaritzburg, pp 18-31

Campbell PL (2000) Rehabilitation recommendations after alien plant control. Plant Protection Research Institute Handbook No. 11. Agricultural Research Council, Pretoria

Duke SO, Blair AC, Dayan FE, Johnson RD, Meepagala KM, Cook D, Bajsa J (2009a) Is (-)-catechin a novel weapon of spotted knapweed (Centaurea stoebe)? J Chem Ecol 35:141-153

Duke SO, Dayan FE, Bajsa J, Meepagala KM, Hufbauer RA, Blair AC (2009b) The case against (-)-catechin involvement in allelopathy of Centaurea stoebe (spotted knapweed). Plant Signal Behav 4:422-424

Dyksterhuis EJ (1949) Condition and management of range land based on quantitative ecology. J Range Manag 2:104-115

Foy CL (1999) How to make bioassays for allelopathy more relevant to field conditions with particular reference to cropland weeds. In: Inderjit I, Dakshini KMM, Foy CL (eds) Principles and practices in plant ecology: allelochemical interactions. CRC Press LLC, Florida, pp 25-33

Foy C, Voigt PW, Schwartz JW (1980) Differential tolerance of Weeping Lovegrass genotypes to acid coal mine spoils. Agron J 72:859-862

Gibbs Russell GE, Watson L, Koekemoer M, Smook L, Barker NP, Anderson HM, Dallwitz MJ (1990) Grasses of Southern Africa. Memoirs of the Botanical Survey of South Africa 58. National Botanical Institute, Pretoria

Gomes PIA, Asaeda T (2009) Spatial and temporal heterogeneity of Eragrostis curvula in the downstream flood meadow of a regulated river. Int J Limnol 45:181-193

Goodall JM (2000) Monitoring serial changes in coastal grasslands invaded by Chromolaena odorata (L.) R. M. King \& Robinson. Dissertation, University of Natal

Goodall JM, Erasmus DJ (1996) Review of the status and integrated control of the invasive alien weed, Chromolaena odorata, in South Africa. Agric Ecosyst Environ 56:151-164

Harper JL (1977) Population biology of plants. Academic Press, London

Henderson L (2001) Alien weeds and invasive plants. Plant Protection Research Institute Handbook No. 12. Agricultural Research Council, Pretoria

Henderson L (2007) Invasive, naturalized and casual alien plants in southern Africa: a summary based on the Southern African Plant Invaders Atlas (SAPIA). Bothalia $37: 215-248$
Henderson L, Goodall JM, Klein H (2003) Pompom weed - an invader of grasslands that threatens conservation and agriculture in South Africa. Pamphlet. Gauteng Department of Agriculture. Conservation, Environment and Land Affairs, Johannesburg

Hoque ATMR, Ahmed R, Uddin MB, Hossain MK (2003) Allelopathic effects of different concentration of water extracts of Eupatorium odoratum leaf on germination and growth behaviour of six agricultural crops. Online J Biol Sci 3:741-750

Huffaker CB, Simmonds FJ, Laing JE (1976) The theoretical and empirical basis of biological control. In: Huffaker CB, Messenger PS (eds) Theory and practice of biological control. Academic Press, New York, pp 41-78

Ikuenobe CE, Anoliefo GO (2003) Influence of Chromolaena odorata and Mucuna pruriens fallow duration on weed infestation. Weed Res 43:199-207

Ito I, Kobayashi K, Yoneyama T (1998) Fate of dehydromatricaria ester added to soil and its implications for the allelopathic effect of Solidago altissima L. Ann Bot 82:625-630

Junttila O (2006) Allelopathy in Heracleum laciniatum: inhibition of lettuce seed germination and root growth. Physiol Plant 33:22-27

Koricheva J (1999) Interpreting phenotypic variation in plant allelochemistry: problems with the use of concentrations. Oecologia 119:467-473

Kotze DC, O'Connor TG (2004) Vegetation variation within and among palustrine wetlands along an altitudinal gradient in KwaZulu-Natal, South Africa. Plant Ecol 146: 77-96

Koutika LS, Sanginga N, Vanlauwe B, Weise S (2002) Chemical properties and soil organic matter assessment under fallow systems in the forest margins benchmark. Soil Biol Biochem 34:757-765

Kruse M, Strandberg M, Strandberg B (2000) Ecological effects of allelopathic plants-a review. NERI Technical Report No. 315. National Environmental Research Institute, Silkeborg

Picman AK, Towers GHN (1982) Sesquiterpene lactones in various populations of Parthenium hysterophorus. Biochem Syst Ecol 10:145-153

Reinhardt C, Kraus S, Walker F, Foxcroft L, Robbertse P, Hurle K (2004) The allelochemical parthenin is sequestered at high level in capitate-sessile trichomes on leaf surfaces of Parthenium hysterophorus. Zeitschrift für Pflanzenkrankheiten und Pflanzenschutz Sonderheft XIX:253-261

Retief E (2002) The tribe Eupatorieae (Asteraceae) in Southern Africa. In: Proceedings of the fifth international workshop on biological control and management of Chromolaena odorata, Durban, South Africa, pp 81-89

Rhind JM (1973) Forage grass cultivars in South Africa. Grass Breeding Information Series No. 1. Department of Agricultural Technical Services (Natal Region), Pietermaritzburg

Roder W, Phengchanh S, Keoboualapha B, Maniphone S (1995) Chromolaena odorata in slash-and-burn rice systems of Northern Laos. Agrofor Syst 31:79-92

Romeo JT (2000) Raising the beam: moving beyond phytotoxicity. J Chem Ecol 26:2011-2014 
Ryan J, Miyamoto S, Stroehlein JL (1975) Salt and specific ion effects on germination of four grasses. J Range Manag 28:61-64

Satoh M, Usami Y, Koizumi H (1989) An assay on allelopathy in weeds with lettuce (Lactuca sativa) seeds. Weed Res 34:330-332

Schmidt SK, Ley RE (1999) Microbial competition and soil structure limit the expression of phytochemicals in nature. In: Inderjit, Dakshini KMM, Foy CL (eds) Principles and practices in plant ecology: phytochemical interactions. CRC, Boca Raton, pp 339-351

StatSoft Inc. (2004) Statistica 6.1 (data analysis software system). Tulsa, Oklahoma

Stowe LG (1979) Allelopathy and its influence on the distribution of plants in an Illinois old-field. J Ecol 67:10651085

Tefera T (2002) Allelopathic effects of Parthenium hysterophorus extracts on seed germination and seedling growth of Eragrostis tef. J Agron Crop Sci 188:306-310

Thorpe AS, Thelen GC, Diaconu A, Callaway RM (2009) Root exudate is allelopathic in invaded community but not in native community: field evidence for the novel weapons hypothesis. J Ecol 97:641-645
Tilman D (1985) The resource-ratio hypothesis of plant succession. Am Nat 125:827-852

van der Laan M, Reinhardt CF, Belz RG, Truter WF, Foxcroft LC, Hurle K (2008) Interference potential of the perennial grasses Eragrostis curvula, Panicum maximum and Digitaria eriantha with Parthenium hysterophorus. Trop Grassl 42:88-95

van Oudtshoorn F (2006) Guide to grasses of southern Africa, 2nd edn. Briza Publications, Pretoria

Viles AL, Reese RN (1996) Allelopathic potential of Echinacea angustifolia D.C. Environ Exp Bot 36:39-43

Wardle DA, Nicholson KS, Rahman A (2006) Influence of plant age on the allelopathic potential of nodding thistle (Carduus nutans L.) against pasture grasses and legumes. Weed Res 33:69-78

Williams LO (1976) Tribe II, Eupatorieae. In: Nash DL, Williams LO (eds) Flora of Guatemala Part XII. Fieldiana, Botany 24(12):32-128, 466-482

Zar JH (2003) Biostatistical analysis, 4th edn. Prentice Hall, New Jersey 